\title{
The Development of Kaiwa Lesson Book with the Content of Indonesian Culture to Improve the Speaking Skill in Japanese Language
}

\author{
Lispridona Diner $^{1}$, Dyah Prasetiani ${ }^{1}$ \\ ${ }^{1}$ Semarang State University, Kampus Sekaran Gunungpati, Semarang, Jawa Tengah \\ 50229, Indonesia
}

\begin{abstract}
The background of the development research is the presence of potentials and problems. The potential is that the lesson book of kaiwa (conversation) used today is in the content of Japanese culture. However, many students have no chance to travel to Japan so that they cannot imagine the location and cultural contexts in the lesson books and found the difficulties in speaking skill. Therefore, the development of the lesson book with the content of Indonesian culture is necessary to improve the speaking skill in Japanese language.

The research tried to find how the development of the lesson book with the content of Indonesian culture improves the speaking skill in Japanese language for the students of Japanese Education of Semarang State University (UNNES). The research used Research and Development (R\&D) steps with the model development procedure of ADDIE (Analysis, Design, Development, Implementation, and Evaluation).

The validation results of media experts from the validation 1 and 2 show the mean of the ideal percentage by $57 \%$ and $92.25 \%$ respectively. The assessment of material experts from validations 1 and 2 show the mean of the ideal percentage of $65 \%$ and $92 \%$ respectively. Then, the validation results of the lesson book experts of lecturers show the mean of the ideal percentage by $83.3 \%$, and that of the material experts of lecturers show the mean of the ideal percentage by $93.75 \%$. The results of the trials conducted to the small groups of 10 and 12 students and the entire students of the first grade from the study program of Japanese Education (UNNES) show the results of $88.54 \%, 93.23 \%$, and $92.20 \%$ respectively. The conclusion of the research is that the lesson book with the content of Indonesian culture is appropriate to use as the lesson book in the lectures of speaking skill for the students of the first grade of Japanese Education at UNNES.
\end{abstract}

Keywords: lesson book, kaiwa

\section{INTRODUCTION}

Language is a product of culture containing the speakers' morals and values. It also shows the distinguishing features of the people containing their cultures (minds). It also applies in Japanese language. However, for Indonesian students, Japanese language is hard to learn since it has different structures and grammars 
from Indonesian language. Indonesian language has the structure of S (Subject) - V (Verb) - O (Object).

For example: $\frac{\text { Saya }}{\mathbf{S}} \quad \frac{\text { makan }}{\mathbf{V}} \quad \frac{\text { nasi }}{\mathbf{O}}$

While Japanese language uses the structure of S (Subject) - O (Object) - V (Verb)

For example: watashi gohan o tabemasu

$\begin{array}{crr}\mathrm{S} & \mathrm{O} & \mathrm{V} \\ \text { Saya } & \text { nasi } & \text { makan }\end{array}$

Because the structure is different, the messages communicated are frequently hard to understand.

Besides, learning Japanese language does not only learn the language, but it should also learn Japanese culture to be able to speak the language in accordance with the appropriate context and situation to avoid misunderstanding.

In the lesson book of kaiwa (conversation) used today, it has the content of Japanese culture so that students have already understood and used the conversation in Japanese culture. However, many students who have not had the chance to travel to Japan cannot image the location and cultural context in the lesson book.

Example 1:

In a conversation:

$\mathrm{A}$ : 来週金閣寺へ行きます。

Raishuu Kinkakuji e ikimasu.

B：そうですか。私も来週行きます。どんな所ですか。

Soudesuka. Watashimo raishuu ikimasu. Donna tokoro desuka.

A : 静かな所です。

Shizukana tokorodesu.

From the sample conversation above, when students do not understand the real condition about kinkakuji (the name of a famous temple in Japan which is a tourist object), they cannot understand why they must respond using the answer shizuku (peaceful). If the location (kinkakuji) is replaced by Borobudur, it will make students easier to imagine the condition of the tourist object which is peaceful.

Example 2:

A : 春に花見をしましたか。

Haruni hanami o shimasuka.

B : はい、しました。

Hai, shimashita.

A : どうですか。

Doudesuka.

B : きれいでした。

Kireideshita.

From the sample conversation above, when students do not understand that, in Japan, in spring, Japanese have the habit of watching blooming sakura flower which is called hanami o shimasu, students cannot respond the conversation well. If the Japanese season in the conversation above is replaced by the habit or condition in Indonesia (e.g. lebaran holiday when Indonesian usually go to hometown (mudik)), it 
will make students easier to respond the conversation appropriately in Japanese language.

The hardship is also experienced by the students of Semarang State University. The results of observation and informal interview with the second semester students of Japanese Education Department of Semarang State University indicated that the students had the difficulties in using Japanese language in daily activities in accordance with the context and situation in Indonesia. The problem is caused by the materials in the lesson books used so far which contain Japanese cultures, contexts, and situations in Japan so that the students found it difficult to imagine the situations.

Based on the facts above, the writer developed a lesson book of kaiwa with the content of Indonesian cultures to improve the speaking skill in Japanese language.

\section{RESEARCH METHOD}

\section{Type and Approach of Research}

The type and approach of research used were the research and development applied in educational field. The educational research and development is the process used to develop and validate research products (Borg and Gall, 1989:624). The result of development research is not only the development of an existing product, but also to find practical knowledge and problems. Concerning the matter, Sugiyono (2011:297) states that the method of research and development is a research method to produce a particular product.

Furthermore, the procedures in the development research applied the procedures of ADDIE. The model consists of five main stages, namely Analysis, Design, Development, Implementation, and Evaluation (Pribadi, 2011:125). The method of research and development is a method used to produce a particular product. The development procedure of ADDIE in the development stages of Borg and Gall only reached the sixth stage. The research and development started from the analysis to find the purpose to the last stage, the sixth stage, to conduct the evaluation with the number of subjects of 30-80

\section{Expert Trials}

The lesson book product was validated by the experts. There were two experts validating the lesson book; the lesson book and material experts. The validity level of the lesson book was found through the analysis results to the trial activities conducted in two stages, i.e.:

1. The test of the lesson book experts of learning and the material experts of lesson. The activities were conducted to review the initial product and provided inputs for improvements.

2. Questionnaires on student's response. The questionnaires were conducted to recognize how the students responded the lesson book and how the students enjoyed learning kaiwa using the lesson book with the content of Indonesian culture. 


\section{Product Trials}

The lesson book products with the content of Indonesian culture which passed the revision stage were tested in the lectures of the second grade students of teh Japanese Education Department of UNNES. The writer delivered the learning materials and applied the materials in the lesson books.

\section{Type of Data}

Basically, the data obtained were quantitative and qualitative. The quantitative data was in the form of numbers obtained from the questionnaire of developmental product assessment and the questionnaire of student's responses made in Likert Scale (stratified scale) and Guttman Scale. The qualitative data was int he form of responses, criticism, and recommendations written in the questionnaires. The data were related to the fit or appropriateness to the development product made.

\section{Research Instrument}

The instrument used was a questionnaire in the form of checklist to get the assessment from the experts on the lesson book quality. The lesson book quality was viewed from several aspects, i.e: material appropriateness, the appropriatenes with the principles of lesson book development, fit and competency presentation. The aspects were described into the indicators and further development by the researchers. The researchers developed the research questionnaires using seven questionnaires in data collection, i.e: the questionnaires of lesson book experts, material experts, lesson book experts of lecturers, trial to 10 students, trial to 12 students, and the assessment (response) to the students participating in lectures.

\section{Data Analysis Technique}

Data analysis was conducted to see the values of each aspect or descriptor in the questionnaires. The data obtained from the questionnaires were given to the experts of lesson book, materials, and student's responses. The collected data were analyzed by counting the average scores. The score analysis used was the descriptive analysis.

\section{RESEARCH RESULTS AND DISCUSSION}

\section{Research Finding}

\section{ANALYSIS}

The analysis in the research was conducted in the analysis to the potentials, problems, library studies, competencies, course learning achievements, materials, and student's development. From the analysis, the data obtained were as follows:

a. Potential analysis: students studies actively 
b. Problem analysis: current learning and appearing problems. The lesson books used were the books with the content of Japanese culture and context so that the students found it difficult to use Japanese language in a conversation. It was supported by the interviews to some students and the observations conducted by the researchers. The results of interviews and observations show that the students have difficulties when using Japanese language in a talk due to their lack of Japanese cultural knowledge.

c. Library study analysis: based on the existing potentials and problems, the researchers tried to find the solution. The solution was based on the library study conducted by the researchers. Then, bawsed on the potential and problems, the researchers developed a lesson book with the content of Indonesian culture. The development refered to the opinion of the expert, Sakri, who said that a lesson book should be challenging, stimulating, and supporting the students' activities and creativities (2008:134)

d. Competence analysis: the researchers analyzed the competencies existed in the material object that would be developed through the learning scope.

e. Learning achievement analysis: the learning achievement analysis in the development of the lesson book was conducted by describing and developing the core and basic competencies into the indicators to achieve in accordance with the Semester Learning Plan applied in UNNES.

\section{DESIGN}

In the design stage, the results show that the design concept of the lesson book with the content of Indonesian culture consisted of six steps, i.e.: 1) curriculum study, 2) syllabus making, 3) book organization, 4) material selection, 5) material presentation, 6) use of language and readability.

\section{DEVELOPMENT STAGES}

The steps made in the processes of development and productio consisted of several steps. To identify the steps, the researchers described the stages in the development and production as follows: 1) determining conversation theme based on the student's skill level, namely basic conversation skill, 2) determining the Indonesian cultures that can be applied in basic Japanese conversation, 3) determining the sentence patterns and vocabularies that can be used in basic Japanese conversation, 4) composing the conversations according to the theme determined from easy (short) conversation, and 5) planning the activities performed in classes to make the students easier in applying the conversations.

The assessment was conducted by validating the lesson books and materials. The data obtained from the assessment results are as follows: 
TABLE 1 FIRST VALIDATION RESULTS OF LESSON BOOK EXPERTS

\begin{tabular}{|l|l|c|c|c|}
\hline No. & \multicolumn{1}{|c|}{ Assessment Aspects } & Average Score & Category & Ideal percentage \\
\hline 1 & $\begin{array}{l}\text { The lesson books were } \\
\text { relevant with the students } \\
\text { competence abilities }\end{array}$ & 22 & $60 \%$ \\
\hline 2 & $\begin{array}{l}\text { The discussion was linear } \\
\text { from the beginning to the end }\end{array}$ & 20 & fair & $58 \%$ \\
\hline 3 & $\begin{array}{l}\text { The lesson books were } \\
\text { adequate (not too little and not } \\
\text { too much) }\end{array}$ & 9 & fair & $45 \%$ \\
\hline 4 & Systematic lesson books & 24 & $65 \%$ \\
\hline
\end{tabular}

TABLE 2 SECOND VALIDATION RESULTS OF LESSON BOOK EXPERTS

\begin{tabular}{|l|l|c|c|c|}
\hline No. & \multicolumn{1}{|c|}{ Assessment Aspects } & Average Score & Category & Ideal percentage \\
\hline 1 & $\begin{array}{l}\text { The lesson books were } \\
\text { relevant with the students } \\
\text { competence abilities }\end{array}$ & 36 & good & $95 \%$ \\
\hline 2 & $\begin{array}{l}\text { The discussion was linear } \\
\text { from the beginning to the end }\end{array}$ & 34 & good & $90 \%$ \\
\hline 3 & $\begin{array}{l}\text { The lesson books were } \\
\text { adequate (not too little and not } \\
\text { too much) }\end{array}$ & 14 & good & $94 \%$ \\
\hline 4 & Systematic lesson books & 35 & & $90 \%$ \\
\hline
\end{tabular}

TABLE 3 FIRST VALIDATION RESULTS OF MATERIAL EXPERTS

\begin{tabular}{|l|l|c|c|c|}
\hline No. & \multicolumn{1}{|c|}{ Assessment Aspects } & Average Score & Category & $\begin{array}{c}\text { Ideal } \\
\text { percentage }\end{array}$ \\
\hline 1 & Appropriateness indicator & 10 & fair & $70 \%$ \\
\hline 2 & Fit indicator & 12 & fair & $60 \%$ \\
\hline 3 & Presentation indicator & 8 & fair & $65 \%$ \\
\hline 4 & Competence indicator & 22 & fair & $65 \%$ \\
\hline
\end{tabular}

TABLE 4 SECOND VALIDATION RESULTS OF MATERIAL EXPERTS

\begin{tabular}{|l|l|c|c|c|}
\hline No. & \multicolumn{1}{|c|}{ Assessment Aspects } & Average Score & Category & $\begin{array}{c}\text { Ideal } \\
\text { percentage }\end{array}$ \\
\hline 1 & Appropriateness indicator & 14 & Very good & $96 \%$ \\
\hline 2 & Fit indicator & 18 & Very good & $90 \%$ \\
\hline 3 & Presentation indicator & 9 & Very good & $94 \%$ \\
\hline 4 & Competence indicator & 30 & Very good & $100 \%$ \\
\hline
\end{tabular}

TABLE 5 VALIDATION RESULTS OF LESSON BOOK EXPERT OF LECTURERS

\begin{tabular}{|l|l|c|c|c|}
\hline No. & \multicolumn{1}{|c|}{ Assessment Aspects } & Average Score & Category & good \\
\hline 1 & $\begin{array}{l}\text { The lesson books were } \\
\text { relevant with the students } \\
\text { competence abilities }\end{array}$ & 17 & good & $60 \%$ \\
\hline 2 & $\begin{array}{l}\text { The discussion was linear } \\
\text { from the beginning to the end }\end{array}$ & 32 & Very good & $38 \%$ \\
\hline 3 & $\begin{array}{l}\text { The lesson books were } \\
\text { adequate (not too little and not } \\
\text { too much) }\end{array}$ & 34 & good & $65 \%$ \\
\hline 4 & Systematic lesson books & 24 & & $30 \%$ \\
\hline
\end{tabular}


TABLE 6 VALIDATION RESULTS OF MATERIAL EXPERT OF LECTURERS

\begin{tabular}{|c|l|c|c|c|}
\hline No. & \multicolumn{1}{|c|}{ Assessment Aspects } & Average Score & Category & $\begin{array}{c}\text { Ideal } \\
\text { percentage }\end{array}$ \\
\hline 1 & Appropriateness indicator & 15 & Very good & $100 \%$ \\
\hline 2 & Fit indicator & 18 & Very good & $90 \%$ \\
\hline 3 & Presentation indicator & 8 & Very good & $95 \%$ \\
\hline 4 & Competence indicator & 30 & Very good & $100 \%$ \\
\hline
\end{tabular}

After the lesson book with the content of Indonesian culture was stated to be fit as the lesson book for learning, the next stage was the implementation of the lesson book. The implementation was divided into three stages; a small group of 10 students, a group of 12 students, and the implementation in the lecture of kaiwa in the study program of Japanese Education of UNNES.

Based on the implementation of the lesson book with the content of Indonesian culture, the students then gave their assessments or responses on the lesson book with the content of Indonesian culture. The students' assessments and responses were stated using the questionnaires (yes-no) adjusted with what the students felt after performing the learning using the media. The followings are the students' responses on the trials implemented:

TABLE 7 TRIAL RESULTS TO 10 STUDENTS

\begin{tabular}{|l|l|c|c|c|}
\hline No. & \multicolumn{1}{|c|}{ Assessment Aspects } & Average Score & Category & $\begin{array}{c}\text { Ideal } \\
\text { percentage }\end{array}$ \\
\hline 1 & Easiness of understanding & 11 & Very good & $100 \%$ \\
\hline 2 & Learning independence & 4.5 & Very good & $87.50 \%$ \\
\hline 3 & Learning activeness & 6.25 & Very good & $87.50 \%$ \\
\hline 4 & Interest in kaiwa learning & 6.25 & Good & $75.00 \%$ \\
\hline 5 & Material presentation in the lesson book & 9.3 & Very good & $87.50 \%$ \\
\hline 6 & Implementation of the lesson book & 9.75 & Very good & $93.75 \%$ \\
\hline
\end{tabular}

TABLE 8 TRIAL RESULTS TO 12 STUDENTS

\begin{tabular}{|l|l|c|c|c|}
\hline No. & \multicolumn{1}{|c|}{ Assessment Aspects } & Average Score & Category & $\begin{array}{c}\text { Ideal } \\
\text { percentage }\end{array}$ \\
\hline 1 & Easiness of understanding & 11 & Very good & $100 \%$ \\
\hline 2 & Learning independence & 4.6 & Very good & $87.50 \%$ \\
\hline 3 & Learning activeness & 6.25 & Very good & $90.63 \%$ \\
\hline 4 & Interest in kaiwa learning & 10 & Very good & $87.50 \%$ \\
\hline 5 & Material presentation in the lesson book & 9.5 & Very good & $100 \%$ \\
\hline 6 & Implementation of the lesson book & 9.75 & Very good & $93.75 \%$ \\
\hline
\end{tabular}

TABLE 9 TRIAL RESULTS TO THE STUDENTS OF SECOND SEMESTER

\begin{tabular}{|l|l|c|c|c|}
\hline No. & \multicolumn{1}{|c|}{ Assessment Aspects } & Average Score & Category & $\begin{array}{c}\text { Ideal } \\
\text { percentage }\end{array}$ \\
\hline 1 & Easiness of understanding & 8 & Very good & $95.10 \%$ \\
\hline 2 & Learning independence & 3 & Very good & $89.71 \%$ \\
\hline 3 & Learning activeness & 6 & Very good & $92.65 \%$ \\
\hline 4 & Interest in kaiwa learning & 15 & Very good & $94.12 \%$ \\
\hline 5 & Material presentation in the lesson book & 8 & Very good & $89.71 \%$ \\
\hline 6 & Implementation of the lesson book & 9 & Very good & $91.91 \%$ \\
\hline
\end{tabular}


Evaluation was used to perfect the product. The evaluation was based on the whole suggestions of the lesson book and material experts as well as the responses of the students. Then, the lesson book with the content of Indonesian culture was stated to be very good as the lesson book for kaiwa learning (speaking skill) so that the suggestion for improvement was not given to the lesson book. Therefore, the lesson book with the content of Indonesian culture is stated to be fit as the lesson book for learning the materials.

\section{Discussion}

The researchers developed the lesson book with the content of Indonesian culture based on the stages of research and development (R\&D). The method used in the research and development was the method of ADDIE. The method of ADDIE was chosen since it is a method used to produce particular product and to test the fit of the product. ADDIE consists of Analysis, Design, Implementation, Evaluation.

The lesson book was developed based on the presence of problem and potential. The potential is that the lesson book of kaiwa (conversation) used until recently has been in the context of Japanese culture so that the students had understood and used the conversation acording to Japanese culture. However, many students who did not have the chance to travel to Japan so that they could not imagine the location and cultural context contained in the lesson book. Therefore, they experienced diffifulties in their speaking skill. Meanwhile, the problem as the basis for the lesson book making was the insufficient knowledge on Indonesian culture that can be implemented easily in the learning process.

The lesson book was then developed based the analysis of the appropriateness with the course materials and student's ability and also based on the learning achievement in the lectures. Next, it was analyzed according to the indicators developed from the competence of each course materials in each meeting. The analysis results were used by the researchers to design the lesson book.

In the development, the media was validated by the experts before tried to recognize the fit. The validators were the experts of lesson book and materials. Based on the assessment results of the experts of lesson book and material, the improvements were conducted in the model of the developed lesson book.

After the lesson book was validated and stated to be fit to use in learning process, it was then tried in the lectures of kaiwa (speaking skill) to see the students' responses. The testing was conducted for the students of the second semester in the study program of Japanese Education of UNNES from the smal group of 10 students and continued to 12 students. Finally, it was tested in one-class trial of the second semester students of the study program of Japanese Education at UNNES.

The validation results with the experts in lesson book obtained the data as follows: 1) in the first validation, the validation of the lesson book was $57 \%$. Therefore, a revision was made and the second validation was held, 2) in the second validation, the ideal level of the lesson book was revised to reach $92.25 \%$ so that the lesson book is fit to use. The data obtained from the validation of the material experts was as follows: 1) in the first validation, the validation of the lesson book was $65 \%$. Therefore, a revision was made and the second validation was held, 2) in the second validation, the ideal level of the lesson book was revised to reach $92 \%$ so that the 
lesson book with the content of Indonesian culture is fit to use. Meanwhile, the data obtained from the validation by the lesson book expert of lecturers show that the ideal level of the lesson book with the content of Indonesian culture was 53.25, and the results of the material validation of the lecturers show the data that the ideal level of the lesson book with the content of Indonesian culture reached $96.25 \%$.

The trials to the lesson book with the content of Indonesian culture were conducted gradually from the small group of 10 students to 12 students. The qualitative data was obtained from the students' responses. The product trials to 10 , 12 , and 60 students showed the average scores of student's response by $88.54 \%$, $93.23 \%, 92.20 \%$ respectively.

Based on the validation by the lesson book experts and student's responses to the implementation of the lesson book with the content of Indonesian cuture, it can be concluded that the lesson book was well-composed. Therefore, the lesson book with the content of Indonesian culture can be the lesson book for the lectures of kaiwa applied in the teaching and learning processes.

\section{CONCLUSION}

The data obtained from the results of the research and development of the lesson book with the content of Indonesian culture conducted to the second semester students from the study program of Japanese Education, UNNES, show that the lesson book with the content of Indonesian culture is fit to use. The data were obtained from the vlidations by the experts of lesson book and material as well as the data from the students' responses. Thus, it can be concluded that, in general, the lesson book with the content of Indonesian culture is fit to use as the lesson book for the second semester students in the lectures of kaiwa in the study program of Japanese Education of UNNES.

\section{REFERENCES}

[1] Borg, W.R. and Gall, M.D. 1989. Educational Research An Introduction.

[2] New York: Longman

[3] Pribadi, Benny A., 2011. Model Desain Sistem Pembelajaran. Jakarta: Dian Rakyat

[4] Sakri, Adjat. 2008. Cara Menulis Buku Ajar. ITB : Bandung

[5] Sugiyono. 2011. Metode Penelitian Kualitatif, Kuantitatif, dan R\&D. Bandung: Alfabeta

[6] Babu, V. dan Kuttia, K. (1996), "Cultural Continuity in Development”, Traditional Dwelling and Settlement, Journal, Vol 96 /IASTE96-96, University of California at Berkeley, Berkeley.

[7] Elina S, Millah. 2012. Pengembangan Buku Ajar Materi Bioteknologi di Kelas XII SMA IPIEMS Surabaya Berorientasi Sains, Teknologi, Lingkungan dan Masyarakat (SETS). http://ejournal.unesa.ac.id/index.php/bioedu/article/view/344/baca-artikel. Diakses tanggal 22 Februari 2014

[8] Harijanto, Mohammad. 2007. Pengembangan Bahan Ajar untuk Meningkatkan Kualitas Pembelajaran Program Pendidikan Pembelajar Sekolah Dasar.

[9] Reigeluth. 1992. Instructional Design Strategies and Tacties. Educational Technology Publications. New Jersey: Englewood Cliffs. 